\title{
ДИСКУРС ЖАХІВ I ТЕКСТ ЖАХІВ: СПРОБА ТЕОРЕТИЧНОГО ВИОКРЕМЛЕННЯ
}

Розвідка присвячена теоретичному облрунтуванню понять дискурс жахів і текст жахів на засадах лінгвістичної прагматики й ставить за мету дослідити особливості текстів як каналів комунікації автора й читача в дискурсивному просторіжахів. Актуальність і перспективність дослідження зумовлені наявним попитом на теоретико-методологічне й практичне вивчення комунікативних процесів у різних дискурсах і формах. Запропонована спроба облрунтування понять дискурс жахів і текст жахів дає передусім відповіді на питання існування критеріїв аналізу комунікації, ускладненої пристрасним компонентом.

Ключові слова: дискурс жахів, дискурсивний простір, текст, комунікаиія, комунікативний смисл «страх».

Sazonova Ya. Horror Discourse and Horror Text: an Attempt of Theoretical Definition. The research is aimed at the theoretical grounding of the notion of the horror discourse and horror text in view of linguistic pragmatics; the purpose of the article is to analyze the specificity of texts as channels of an author-readers' communication in the discourse space of horror. If we recognize that the discourse space of horror consists of different channels of communication united by the common intention - to impose the communicative sense of fear with various pragmatic reasons, we shall see that this space is governed by the universal character of fear as one of the integral parts of humans' existence. To achieve this aim the following steps are consequentially made: we defined and theoretically grounded the notion of the horror discourse; we proved that within the domain of linguistic pragmatics a horror text is one of the channels of communication complicated by some passion; we singled outed and listed the specific features of a horror text. The topicality and future perspectives of the research are motivated by the growing interest in theoretical-methodological and practical investigations of the communicative processes in various discourses and forms. The suggested attempt of grounding the notions of the horror discourse and horror text, first and foremost, answers the question of the possible criteria of analyzing communication, complicated by some passion or an emotional component.

The presented research proves that the suggested approach to the analysis of texts and discourses is perspective because, firstly, it allows the analysis of texts with other communicative senses-passions; secondly, the communicative sense "fear" may have a secondary function in "passionate" texts of some other intentional directionality and only accompany other communicative senses.

Key words: horror discourse, discursive space, text, communication, communicative sense "fear". 


\section{Вступ}

Текст можна вивчати традиційно, у вимірі лінгвістики тексту, визначаючи формально-структурні чи формально-змістовні компоненти, або спертися на літературознавчу традицію жанрової відповідності твору (історичний роман, детектив, комедія, химерна проза тощо). Однак ці підходи не задовольняють тих, хто націлений на вивчення актуальних проблем комунікації. Синкретичність сучасної словесної художньої творчості, накопичений людством доробок і швидкі зміни в уподобаннях авторів та читачів становлять і цікавинку для сучасного філолога, і науковий виклик, і проблему, адже вони не дозволяють уповні охопити потік мовного матеріалу й узяти до уваги його різноманітність, історичну зумовленість, взаємний вплив культур, особистість автора та інші чинники, які могли б сприяти систематизації усного або письмового спілкування.

Дослідження в царині лінгвістичної прагматики мають тенденцію до вивчення комунікації в діалогічному спілкуванні (в усній або писемній формах), чому сприяли ідеї Ф. Бацевича, Л. Вітгенштейна, Г. П. Грайса, Т. ван Дейка, Дж. Ліча, Дж. Остіна, Дж. Сьорля, П. Строссона, I. Сусова, Р. Якобсона та інших науковців. Водночас спостерігається певний дисбаланс щодо уваги до тексту як одиниці комунікації (на це вказують В. Богданов, Т. ван Дейк, М. Димарський, Т. Радзієвська, О. Ревуцький, К. Сєрова).

Мета цього дослідження - теоретично обгрунтувати особливості текстів жахів як каналів комунікації автора й читача в дискурсивному просторі жахів. Для досягнення цієї мети з'ясуємо й теоретично обгрунтуємо поняття дискурс жахів; доведемо, що в межах обраного дослідницького підходу текст жахів - це один з каналів комунікації, ускладненої пристрасним компонентом; перелічимо лінгвопрагматичні особливості такого тексту.

\section{Методи та методики дослідження}

Розвідка здійснена в межах лінгвістичної прагматики, яка визнана одним з найсучасніших підходів до дослідження мовних явищ iз урахуванням загальної антропоцентричної парадигми мовознавства сьогодення. «Лінгвістична прагматика $<\ldots>$ взаємодіє з різними позалінгвістичними дисциплінами, може залучати їхні ідеї й прийоми роботи з матеріалом, але інтерпретувати їх на користь мовознавства» 
(Сусов, 2009: 40). Запропонований підхід до дослідження текстів відповідає вимогам застосування діяльнісного принципу в прагматиці. Як зазначає I. Сусов, саме лінгвістична прагматика бере до уваги соціально-комунікативну інтеракцію суб'єктів спілкування, враховуючи й поєднуючи у своєму аналізі мовні й позамовні чинники такого спілкування (Сусов, 2009: 40).

\section{Результати та дискусії}

У цьому дослідженні вводимо до обігу термін «дискурс жахів», який потребує обгрунтування, що, на нашу думку, можливо із застосуванням загальновідомого поняття «дискурсивний простір». Та який би вияв комунікації ми не досліджували (усний, письмовий чи інший), слід визнати існування дискурсивного простору - території адресанта й адресата (Сар, 2013: 5); «дискурсивний простір - це прагматична форма контексту, що використовується для структурування знань, що містяться в дискурсі. Дискурсивні простори створюються, оновлюються або пробуджуються агентом, який намагається генерувати чи зрозуміти дискурс» (Moulin, 1995: 89), що не суперечить й іншій дефініції дискурсу в найширшому тлумаченні: «різноманітна комунікація з приводу конкретної теми, наприклад, дискурс прав людини або дискурс Святого Отця» (Fetzer, 2014: 35). Цей термін використовують у різних галузях гуманітарних досліджень (як зазначають Г. Лушникова та Є. Медведєва, він знаходиться в обігу літературознавства, різних течій мовознавства, соціальних наук (Лушникова, Медведева, 2013)).

Значною мірою поняття дискурсивного простору привласнене представниками когнітології, які стверджують, що дискурс - це поняття когнітивне за своєю природою, призначене для обміну знаннями (Кубрякова, 2004), або що створення дискурсів і їхніх просторів притаманне дискурсивній особистості з певною когнітивною компетенцією (Плотникова, 2009). Ці переконливі спостереження, на нашу думку, потребують уточнення, а саме - розширення переліку компетенцій дискурсивної особистості, до яких природним чином увіходить і комунікативна компетенція. Такий погляд лише додасть об'єктивності теоретичним засадам вивчення дискурсу, а також дозволить сприймати термін дискурсивний простір як універсальний загальнофілологічний. На підтвердження цієї думки наведемо 
тлумачення й аргументи когнітологів, що можуть бути потрактовані в більш узагальненому сенсі. Наприклад: «Дискурсивний простір розуміють як певне логічне середовище, у якому співіснують дискурси й дискурсивні особистості - люди, які продукують ці дискурси» (Плотникова, 2009), але комунікація й інтеракція людей не завжди підпорядкована логіці (наприклад, у текстах жахів страхітливі суб’єкти аномальні, увесь вигаданий світ жахів саме й підпорядкований тому, що в ньому руйнується звичний логічний світ, як і у світі фенетезі або наукової фантастики).

У згаданому вище твердженні О. Кубрякової, на нашу думку, немає місця дискурсивному простору художнього тексту, адже він відсторонений від безпосереднього обміну знаннями між комунікантами, хоча серед переліку дискурсивних просторів знаходимо поруч із масмедійним, політичним, науковим дискурсом і художній дискурс також. Пристрасний дискурс, поняття про який уведене в обіг А. Греймасом і Ж. Фонтанієм, не був об’єктом дослідження в цьому сенсі взагалі, хоча концепт СТРАХ у мовознавстві вивчений достатньо. Якщо ж спробувати проаналізувати дискурсивний простір не як логічне когнітивне середовище, а як антропоцентричне гуманітарне, то, дійсно, поняття дискурсивного простору висувається на вищий рівень і може бути застосоване й для дослідження пристрасного дискурсу також.

У цьому сенсі дискурс жахів - це поєднання просторів художнього й пристрасного дискурсів, що існує в антропоцентричному гуманітарному середовищі, де поєднуються знання й психологія, суб'єктивність і об'єктивність комунікантів; у просторі дискурсу жахів комунікантами (дискурсивними особистостями) генерується, транслюється й сприймається базовий комунікативний смисл «страх»; каналами комунікації цього дискурсу вважаємо тексти, фільми, картини й будь-які інші варіанти здійснення такої комунікації. Зі змістовного боку дискурс жахів - це такий простір, який містить уявлення людини про норму й відхилення, своє й чуже, безпечне й загрозливе тощо, і ці уявлення на основі психічних властивостей людини, а також іiі аналітичних здібностей постійно генерують конфлікт суб’єктів, що й стає основою страху. Матеріалізована у вигляді текстів дискурсу жахів комунікація згенерована адресантом з певною інтенцією впливу на адресата. 
Художній дискурс увіходить до категорії мережевих дискурсивних просторів, «у яких відношення «стимул-реакція» засновані на певному колективному «мережевому розумі», коли смисли i, відповідно, дискурси детерміновані іншими смислами й дискурсами, і близькими, і досить далекими, коли все взаємопов'язане і взаємопроникне» (Плотникова, 2009). Уникаючи метафізичних крайнощів типу «колективний «мережевий розум»», пропонуємо розглянути дискурс жахів як комунікативний феномен, що укорінений в основах людської психіки й свідомості, які аналітично переосмислені й чітко сформульовані у відповідних науках. Слушною вважаємо думку про вплив інших дискурсів, не лише споріднених, а й віддалених від основного комунікативного смислу, наприклад, існування взаємного впливу пристрасного й політичного дискурсів (див. Сар, 2017; Sazonova, 2016).

Дискурс жахів як простір підпорядковується й іншим характеристикам, що їх було виокремлено вченими-когнітологами, наприклад, його інтерактивність: «<..> його учасники зацікавлені в координації один з одним, в особливому фоновому просторовому консенсуci, у створенні певного просторового настрою, взаємної впевненості в «правильності» вироблених дискурсів. У спільному дискурсивному просторі з'являються особливі стандарти, такі, як потреба в згоді / незгоді, взаємна санкціонованість, солідарна відповідальність, взаємоспрямований вплив» (Плотникова, 2009). Підтримуємо думку Н. Олізько, яка зазначає, що художній дискурс - це діалог автора, читача й тексту, це взаємодія авторських інтенцій, складного комплексу можливих реакцій читача й тексту (Олизько, 2011). У проекції на дискурс жахів інтерактивність реалізується в збігові інтенції адресанта виразити та намірів і можливості адресата сприйняти базовий комунікативний смисл «страх» (у термінах С. Плотникової - особливий фоновий просторовий консенсус), іншими словами - в актуалізації цього смислу.

Підтримуємо також думку С. Плотникової про здатність дискурсивного простору до самопородження й самоструктуризації: «Він формується дискурсами, що в ньому виникають, але також має межі можливого; вони з'ясовуються, коли дискурси стають несумісними й 3-поміж них виникають напружені стосунки. Щоб дискурсивний простір не руйнувався, необхідні зміни в збудженій ділянці 
ланцюжка, або «відокремлення» нового дискурсивного поля від попереднього (це відбувається, зокрема, у процесі утворення нового жанру)» (Плотникова, 2009). Слідом за С. Плотниковою цю ідею розвивають Г. Лушникова та Є. Медведєва, стверджуючи, що «художній дискурсивний простір становить постійно наявний мережевий дискурсивний простір, який об'єднує однотипні (художні) дискурси» (Лушникова, Медведева, 2013). Визнаємо наявність універсальних механізмів і способів утілення комунікативного смислу в межах тексту, як і специфічність засобів їхнього омовлення.

Такий стан речей надихає на спробу застосування іншого підходу до вивчення текстів як одиниць комунікації, що має за основу визнання комунікативного смислу цілого тексту і його належність до пристрасного дискурсу. На важливість вивчення смислу дискурсів вказує й А. Фетцер, коли говорить, що дискурс не потрібно обмежувати кодом мови або ії одиницями типу речення, адже цей смисл не дорівнює сумі смислів речень або висловлювань (Fetzer, 2014). На думку Г. Відоусона, дискурс-аналіз «повинен мати справу не з тим, що текст значить, а з тим, що може бути ним виражене, і з тим, що передбачене для вираження. У зв'язку із цим не можна говорити про «розуміння» тексту як про семантичний процес, а насамперед про прагматичну «оцінку», яка вводить контекст у гру» (Widdowson, 2004: 35); «дискурс - це прагматичний процес досягнення порозуміння щодо певного смислу. Текст - його результат» (ibid.: 8).

Схожі ідеї, хоча й у царині лінгвістики тексту (його поетики), висловлює А. Богатирьов, коли пропонує удосконалювати динамічну теорію художнього тексту, іншими словами - бачити в тексті комунікацію автора й читача. Предметом його дослідження стали «схеми унаочнення засобів текстової організації, до смислового навантаження яких входить вказівка на тип інтенції цілого тексту» (Богатырев, 2001: 5). А. Богатирьов пропонує також для аналізу спільний родовий початок смислопородження художніх текстів («адекватному конструюванню продуцентом тексту горизонтів читацьких смислових очікувань відносно авторської програми тексто- й смислопобудови слугують схеми індивідуації родового змістовного початку» (ibid.: 8). Убачаємо в цьому підхід, подібний до запропонованого тут, коли родовим змістовним початком породження тексту стає психолого-філософська основа феномену страху, узагальнена базовим 
комунікативним смислом. На основі комунікативного смислу «страх» зразки комунікації (і тексти як матеріалізоване спілкування автора й читача) відносимо до дискурсу жахів. I дійсно, «мовний текст - слід опредметненої комунікативної діяльності продуцента» й «майданчик для розуміння, яке розпредметнює» (ibid.: 12).

Визнання комунікативного смислу тексту дозволить не зважати на літературознавчу традицію класифікації художніх текстів. Такий підхід виключно антропоцентричний, чого вимагають сучасні гуманітарні науки, і комунікативно спрямований, що вкладається в зазначене поле лінгвістичної прагматики. Як вказує Ф. Бацевич, «важливо також зазначити, що прагматичні значення (комунікативні прагматичні смисли) стосуються, передовсім, внутрішнього світу учасників спілкування (почуттів, емоцій, психологічних і психічних станів, вірувань, волі, культурних чинників тощо); вони є надзвичайно складно формульованими, а тим більше дефінійованими, формалізованими i, як правило, сприймаються й «декодуються» іншими учасниками спілкування, виходячи з власних комунікативних навичок, власного світосприйняття» (Бацевич, 2010: 28) Так само у Ф. Бацевича знаходимо зауваження щодо проблемних питань лінгвістичної прагматики, серед яких відсутність «усіх можливих прагматичних комунікативних смислів у більш-менш стандартизованих, типових контекстах певної лінгвокультури» (ibid.: 42).

Відповідно, художні тексти визнаємо зразками пристрасного дискурсу, де базовим комунікативним смислом усього тексту постає певна пристрасть, у цьому разі - страх. Актуалізація комунікативного смислу здійснюється в процесі комунікації автора (адресанта) й читача (адресата). І якщо суб’єктивність в ії вияві в мовленнєвій діяльності $є$ основною категорією лінгвістичної прагматики (Бацевич, 2010; Степанов, 2002), то консенсус інтенції й сприйняття суб’єктів комунікації (адресанта й адресата) дорівнює вдалій комунікації в межах пристрасного дискурсу жахів. Очевидно, що суб'єкт (автор) впливає на об’єкт (читача) з метою «досягнення конкретного результату, користуючись для цього певними способами і використовуючи потрібні засоби (інструменти). Суб’єктом рухає конкретний намір (інтенція) перетворення об'єкта. Кожна дія відбувається в межах певної ситуації (місце, час, обставини тощо), усвідомлення цієї ситуації суб’єктом, тобто за наявності фонових знань про світ, правила 
діяльності, плановий кінцевий результат тощо. Досягнення результату передбачає наявність мотиву, задуму, схеми дій, плану, стратегій, тактик та інших складників» (Бацевич, 2010: 35).

Це положення потребує коментарів щодо його застосування для вивчення текстів жахів як зразків пристрасного дискурсу. Передусім постає питання про інтенцію суб'єкта й результат його впливу на об'єкт у процесі сприйняття тексту дискурсу жахів: звичайно, що автор не намагається вплинути на читача 3 наміром налякати. У разі, коли йдеться про пристрасний дискурс (жахів тощо), інтенція автора не має іншого пояснення, окрім психологічної або естетичної природи переживання цієї пристрасті, тобто звернення до міждисциплінарних сфер. Запропонований підхід до дослідження текстів пристрасного дискурсу відповідає вимогам застосування діяльнісного принципу в прагматиці. Як зазначає I. Сусов, саме лінгвістична прагматика бере до уваги соціально-комунікативну інтеракцію суб'єктів спілкування, враховуючи й поєднуючи у своєму аналізі мовні й позамовні чинники такого спілкування (Сусов, 2009: 40), тому філософські й соціокультурні чинники дозволяють говорити про культурно-естетичний, суспільно-політичний, релігійний та інші впливові мотиви комунікації в межах дискурсу жахів, особливо на сучасному етапі.

Пояснення також вимагають обставини спілкування автора й читача: як вказувалося вище, читач - це неозначена кількість осіб, які долучаються до комунікації з автором у різні часи й за різних обставин, тому й «ситуацій» безліч. Наприклад, можна з упевненістю говорити, що текст «Дракули» Б. Стокера (Stoker, e-текст) у сприйнятті тогочасного читача абсолютно відрізняється від реакції сучасного адресата: сьогодні він швидше сприймається як культурний артефакт відповідного періоду розвитку дискурсу жахів, що став джерелом інтертекстуальності в дискурсі жахів (хоча не виключені й особливо чутливі особистості, які досі мають сприйняття на рівні позаминулого сторіччя). Тому інтенція автора може полягати в дидактичній функції (наприклад, давні тексти релігійного спрямування в українській літературі (див. «Чорт зна що» Ю. Винничука) (Винничук, 2004)), у функції саморефлексії (переживання «безпечних» емоцій), виховній функції (розвинення емпатії й емоційного інтелекту), естетичній функції (насолода від майстерності автора створити вигаданий світ мовними засобами). 
Текстотворення в дискурсі жахів відповідає інтенції автора виразити комунікативний смисл з метою виконання однієї або кількох з перелічених функцій; текстосприйняття в дискурсі жахів - це процес декодування тексту з метою зрозуміти авторську інтенцію; воно культурно-історично, соціально, індивідуально-психологічно й темпорально зумовлене. Обидва процеси є виявом суб’єктивності й діяльнісного принципу як категорій лінгвістичної прагматики.

Слід наголосити на розрізненні понять суб'єктивність і суб'єкmність у прагматичному дослідженні тексту. Якщо суб'єктивність - це поняття рівня комунікації автор-читач і текстотворення та текстосприйняття, то суб'єктність, вважаємо, - це поняття внутрішньотекстового рівня, коли у світі пристрасного дискурсу жахів відбувається поділ суб'єктів на суб'єкт-джерело страху й суб'єкт-реципієнт страху. Уводячи поняття суб'єктності, спираємось на принцип «символічної системи версії світу» Н. Гудмена, а також ідею У. Куайна про специфічну «онтологію вигаданого світу». Суб'єкт-суб'єктні пристрасні відношення в тексті постають основою текстотворення в дискурсі жахів. Суб'єктність - це основа будь-якого тексту художнього дискурсу, а за обставин його віднесеності до дискурсу пристрастей стає основою текстотворення. Текстове втілення суб'єкт-суб'єктних пристрасних відношень - це спосіб побудови вигаданого світу дискурсу жахів, де розрізнення суб’єктів пристрасті - перший етап актуалізації комунікативного смислу «страх», а референція й номінація - це стратегії його мовного втілення.

Способи й засоби втілення інтенції автора в процесі створення тексту жахів, а також стратегії й тактики актуалізації комунікативного смислу не є об’єктом цього дослідження та лежать у перспективній площині, але це потребує узагальнення рис, що, на нашу думку, має текст жахів як зразок пристрасного дискурсу:

- тексти жахів мають потенційно актуалізований комунікативний смисл - певна пристрасть (у нашому разі - феномен страху);

- цей смисл може бути актуалізований чи ні залежно від спільного соціокультурного, історичного й психологічного фону адресата й адресанта;

- комунікативний смисл тексту актуалізується за умови породження суб’єкт-суб'єктних пристрасних відношень (суб’єктності тексту жахів) у сприйнятті читача та інтенції автора; 
- у творенні текстів реалізуються комунікативні смисли культурного й духовно-психологічного характеру [1], тому авторська інтенція може бути повчальна і / або естетична, і / або виховна, і / або саморефлексії;

- реалізація принципу суб’єктивності в текстах пристрасного дискурсу - це долучення учасників комунікації до вигаданого світу шляхом додавання власного розуміння певної пристрасті до загального i, навпаки, шляхом спільного переживання цієї пристрасті;

- тексти жахів як канали комунікації в дискурсі жахів характеризуються комунікативною диспропорцією, тобто відсутністю зворотного зв'язку, наявністю одного адресанта й безлічі адресатів у часі й просторі, що може впливати на успішність комунікації.

\section{Висновки}

Здійснена спроба теоретико-методологічного обгрунтування понять дискурс жахів і текст жахів дає відповіді насамперед на питання щодо існування критеріїв аналізу комунікації, ускладненої пристрасним компонентом. Визнання дискурсивного простору жахів насиченим різними каналами комунікації, але об'єднаним спільною інтенцією - трансляцією комунікативного смислу страх з різними прагматичними намірами - базується на універсальному характерові страху як одного з невід'ємних складників людського існування. Тексти жахів за такого підходу мають перелік лінгвопрагматичних особливостей, що їх перелічено внаслідок аналізу й переосмислення ідей багатьох учених різних галузей гуманітарних досліджень. Спілкування автора й читача в дискурсі жахів, а водночас і текстотворення та текстосприйняття, базуються на принципах суб’єктності й суб’єктивності, що відбивають пристрасний комунікативний і змістовний складники текстів жахів як зразків цього дискурсу.

Можна з упевненістю стверджувати, що перспективність такого підходу очевидна, адже, по-перше, перспективним виявиться й вивчення текстів з іншими комунікативними смислами-пристрастями, наприклад, кохання; по-друге, комунікативний смисл «страх» може виступати не основним у текстах, виділених на комунікативних засадах, а супроводжувати комунікативні смисли в текстах іншої інтенційної спрямованості. 


\section{ЛІТЕРАТУРА}

1. Бацевич Ф. С. Нариси $з$ лінгвістичної прагматики. Львів: ПАЇС, 2010. 336 с. 2. Богатырев А. А. Индивидуация интенционального начала беллетристического текста: дис. ... докт. филол. наук. Тверь, 2001. 3. Винничук Ю. Вибрики українського чорта. Чорт зна що. Львів: ЛА ПІРАМІДА, 2004. С. 11-14. 4. Кубрякова Е. С. Язык и знание. На пути получения знаний о языке: части речи с когнитивной точки зрения. Роль языка в понимании мира. Москва: Языки славянской культуры, 2004. 560 с. 5. Лушникова Г. И., Медведева Е. В. Дискурсивное пространство фэнтези (на материале произведений А. Нортон). Современные проблемы науки и образования. 2013. № 6. URL: https:// www.science-education.ru/ru/article/view?id=11573. 6. Олизько Н. С. Художественный дискурс как полилог автора, читателя и текста. Вестник Челябинского гос. ун-та. Серия «Филология. Искусствоведение». 2011. № 60 (33). С. 64-166. 7. Плотникова С. Н. Дискурсивное пространство: к проблеме определения понятия. 2009. URL: https://cyberleninka.ru/article/v/ diskursivnoe-prostranstvo-k-problemeopredeleniya-ponyatiya. 8. Степанов Ю. С. Имена. Предикаты. Предложения: семиологическая грамматика. Москва: Эдиториал УРСС, 2002. 360 с. 9. Сусов И. П. Лингвистическая прагматика. Винница: Нова кныга, 2009. 200 с. 10. Сар Р. Proximization: The Pragmatics of Symbolic Distance Crossing. Amsterdam-Philadelfia: John Benjamins Publishing Company, 2013. Vol 232. 213 p. 11. Cap P. The Language of Fear: Communicating Threat in Public Discourse. Basingstoke: Palgrave, 2017. 195 p. 12. Fetzer A. Conceptualising discourse. Pragmatics of Discourse. Berlin / Boston: Walter de Gruyter GmbH, 2014. P. 35-64. 13. Moulin B. Discourse Spaces: A Pragmatic Interpretation of Contexts. Conceptual Structures: Applications, Implementation and Theory. SpringerVerbag, 1995. P. 105-114. 14. Sazonova Ya. Yu. Colonial and Postcolonial Influence on Verbalising Subjects-sources of Fear in Ukrainian Texts of Horror Literature. The Proceeding Edition of Scientific Articles, Vilnius University, Kaunas Faculty, Department of Foreign Languages, Kaunas, 2016. P. 331-346. 15. Widdowson H. G. Text, Context, Pretext: Critical Issues in Discourse Analysis. Oxford: Blackwell, 2004. 482 p.

\section{REFERENCES}

1. Batsevich, F. S. (2010). Narysy z lingvistychnoyi pragmatyky [Notes on Linguistic Pragmatics]. Lviv: PAÏS [in Ukrainian]. 2. Bogatyrev, A. A. (2001). Individuaciya intencionalnogo nachala belletristicheskogo teksta [Individuation of the Intentional Beginning of the Fictional Text]. Doctor's thesis. Tver [in Russian]. 3. Vynnychuk, Yu. (2004). Vybryky ukrajinskogo chorta [Ukrainian Devil's Tricks]. Chort zna shho - What's the Devil?, (11-14). Lviv: LA PIRAMIDA. [in Ukrainian]. 4. Kubryakova, E. S. (2004). Yazyk i znanie. Na puti polucheniya znanij o yazyke: chasti rechi s kognitivnoj tochki zreniya. Rol yazyka v ponimanii mira [Language and knowledge. On the way of getting knowledge about language: parts of speech from the cognitive point of view. The role of language in the world perception]. Moskva: Yazyki slavyanskoj kultury [in Russian]. 5. Lushnikova, G. I., Medvedeva, E. V. (2013). Diskursivnoe prostranstvo fentezi (na materiale proizvedenij A. Norton) [Discursive space of fantasy (on the material of A. Norton's works). Sovremennye problemy nauki i obrazovaniya - Modern problems of science and education, 6. Retrieved from https:// www.science-education.ru/ru/article/view?id=11573. 6. Olizko, N. S. (2011). Hudozhestvennyj diskurs kak polilog avtora, chitatelya i teksta [Fictional discourse as polylogue of the author, reader and 
text]. Vestnik Chelyabinskogo gos. un-ta. Seriya «Filologiya. Iskusstvovedenie» - Philology and Art, 60 (33), 64-166 [in Russian]. 7. Plotnikova, S. N. (2009). Diskursivnoe prostranstvo: $k$ probleme opredeleniya ponyatiya [Discursive space: to the problem of the definition of the notion]. Retrieved from https://cyberleninka.ru/article/v/ diskursivnoe-prostranstvo-k probleme-opredeleniya-ponyatiya [in Russian]. 8. Stepanov, Yu. S. (2002). Imena. Predikaty. Predlozheniya: semiologicheskaya grammatika [Names. Predicates. Sentences: semiological grammar]. Moskva: Editorial URSS [in Russian]. 9. Susov, I. P. (2009). Lingvisticheskaya pragmatika [Linguistic pragmatics]. Vinnica: Nova knyga [in Russian]. 10. Cap, P. (2013). Proximization: The Pragmatics of Symbolic Distance Crossing. (Vol 232). Amsterdam-Philadelfia: John Benjamins Publishing Company. 11. Cap, P. (2017). The Language of Fear: Communicating Threat in Public Discourse. Basingstoke: Palgrave. 12. Fetzer, A. (2014). Conceptualising discourse. Pragmatics of Discourse, (pp. 35-64). Berlin / Boston: Walter de Gruyter GmbH. 13. Moulin, B. (1995). Discourse Spaces: A Pragmatic Interpretation of Contexts. Conceptual Structures: Applications, Implementation and Theory, (pp. 105-114). Springer-Verbag. 14. Sazonova, Ya. Yu. (2016). Colonial and Postcolonial Influence on Verbalising Subjects-sources of Fear in Ukrainian Texts of Horror Literature. The Proceeding Edition of Scientific Articles, (pp. 331-346). Vilnius University, Kaunas Faculty, Department of Foreign Languages, Kaunas. 15. Widdowson, H. G. (2004). Text, Context, Pretext: Critical Issues in Discourse Analysis. Oxford: Blackwell.

Сазонова Ярослава Юріӥвна - доктор філологічних наук, доцент, професор кафедри англійської фонетики і граматики, Харківський національний педагогічний університету імені Г. С. Сковороди; вул. Валентинівська, 2, м. Харків, 61168, Україна.

E-mail: sazonova.yaroslava.hnpu@gmail.com

https://orcid.org/0000-0001-9249-448X

Sazonova Yaroslava - Doctor of Philology, Assistant Professor, Department of English Grammar and Phonetics, H. S. Skovoroda Kharkiv National Pedagogical University; Valentynivska Str. 2, Kharkiv, 61168, Ukraine. 